\title{
EDITORIAL
}

\section{Education Should Return to Its Essence}

Annalisa Morganti, ${ }^{1}$ Marta Pellegrini ${ }^{2}$

1. Department of Philosophy and Social, Human and Educational Sciences, University of Perugia, Italy

2. Department of Education, Languages, Intercultures, Literatures and Psychology, University of Florence, Italy

"Education is what remains after one has forgotten what one has learned in school."

-Albert Einstein

7 HE essence of education is an old topic. It is not only a theoretical problem, but also a practical problem. The essence of education is directly related to the answer to "What is education?", and how to answer "What is education?" directly determines the way and content of education. On this basis, the statements about the nature of education also guide and standardize people's educational concepts and behaviors (Shi, 2018). It can be said that human beings have been thinking about this issue since they have had educational practices. After the independence of the educational discipline, the discussion about the essence of education has become a basic problem of pedagogy. Scholars try to find answers to other specific educational questions by solving "What is education?"

As the first educational thinker of modern world education, Comenius was the first to answer questions about the essence of education. He believed that education is "the universal art of teaching everything to all people" (Comenius, 1896).

In the 17th century, the British educator Locke put forward the "whiteboard theory", advocating that the human mind is a blank paper, "the human mind has no talent principle". Through education, learners can master knowledge and virtues (Locke, 1970).

(C) 2021 Insights Publisher. All rights reserved.

(i) (8) Creative Commons Non Commercial CC BY-NC: This article is distributed under the terms of the Creative Commons Attribution-NonCommercial 4.0 License (http://www.creativecommons.org/licenses/by-nc/4.0/) which permits non-commercial use, reproduction and distribution of the work without further permission provided the original work is attributed by the Insights Publisher. 
In the 18th century, French educator Rousseau proposed "Nature Education". He pointed out that the task of education is to free children from the shackles of society and return to nature" and cultivate natural persons (Rousseau, 2010).

In the 19th century, German educator Herbart defined pedagogy as a science based on practical philosophy and psychology in his masterpiece "General Pedagogy". He believed that the purpose of education is "virtue," and the way of education is "teaching" (Herbart, 1806).

Ushinsky, known as the "founder of Russian educational science", discussed education in both broad and narrow sense. He believes that education in a broad sense is unconscious education. Nature, family, society, people and their religion and language are all educators. In the narrow sense of education, the school is the educator who bears the actual responsibility and the teacher is the educator. A sound education can make the physical, intellectual and moral powers of human beings widely used (Ushinsky, 2002).

In the 20th century, Dewey started from the philosophy of pragmatism and advocated "education is growth" and believed that "education is the transformation or reorganization of experience. This transformation or reorganization can not only increase the meaning of experience, but also improve the ability to guide the subsequent process of experience" (Dewey, 1903).

As a result, educators in different periods have put forward different views on education according to their own philosophical views, but the core is that education is an activity to cultivate people, and the focus of education should always be around students (Yang, 2021). From this perspective, we can answer the essential question of education, which can be summarized as that education is an activity that improves the quality of individual life and the value of life.

It is also based on this view of the essence of education that people often need to determine the content and methods of education according to the development needs of students when carrying out educational activities. For example: Inclusive education aimed at helping children with and without certified disabilities embracing all human diversities; Innovative education aimed at cultivating students' innovative ability; and information technology education to better promote the development of students.

The articles published in this issue of SIEF explain the answer to the essence of education from a different perspective. Marsili et al. (2021) "The Italian leadership on inclusive education: myth or reality? The Italian leadership on inclusive education: myth or reality?" answered from the perspective of inclusive education that education should accommodate all students. There is no exclusion, no discrimination, and no classification of all personnel activities. Meng (2021) "How to Use Activities to Realize the SelfManagement of Middle School Students?" emphasized that education should be based on the development needs of students, create activities for students' self-development, and realize students' self-management. Zhang (2021) "The Construction of Innovative Education Curriculum System for High School Students: Based on the Practice of 'Workshop + Project' Innovative Educa- 
tion Curriculum of Zhengzhou No. 12 Middle School, China" called for the cultivation of students' practical ability and innovative consciousness in education and teaching. Gu et al. (2021) "Does Abracadabra Help Improve the English Reading Ability of Chinese Elementary School Students? A QuasiNatural Experimental Study" presented a specific education method, that is, the use of electronic software to improve students' learning ability. While answering the original question, education also needs to be integrated with the times and society, Wang (2021) "A Review of the Development of the Integration Strategy of Information Technology and Education in the Four Countries of the United States, Britain, China, and Singapore" endowed education with distinctive characteristics of the times. It paid attention to the education informatization policies in different countries and different eras, linked education and informatization policies, and highlighted the social and contemporary characteristics of education.

What is education? Various definitions have the background of the times and the author's judgment. How to correctly understand these definitions requires clarification and analysis. SIEF hopes to use this series of articles to explain the essence of education in a more comprehensive way, and to help everyone better understand and interpret the basic question of what education is.

\section{References}

Comenius, J.A. (1896). The great didactic. Рипол Классик.

Dewey, J. (1903). Democracy in education. The elementary school teacher, 4(4):193-204.

Gu, H., Yao, J., Bai, P., Zhou, L., Cheung, A.C.K., \& Abrami, P.C. (2021). Does Abracadabra help improve the English reading ability of Chinese elementary school students? A quasi-natural experimental study. Science Insights Education Frontiers, 9(2):1221-1240. DOI: https://doi.org/10.15354/sief.21.re041

Herbart, J.F. (1806). Allgemeine Pädagogik aus dem Zweck der Erziehung abgeleitet. Röwer, Göttingen. [German]

Locke, J. (1970). Some thoughts concerning education, 1693. Scolar Press.

Marsili, F., Morganti, A., \& Signorelli, A. (2021). The Italian leadership on inclusive education: Myth or reality? Science Insights Education Frontiers, 9(2):1241-1263. DOI:

https://doi.org/10.15354/sief.21.re045 
Meng, W., \& Ning, F. (2021). How to use activities to realize the selfmanagement of middle school students? Science Insights Education Frontiers, 9(2):1305-1318. DOI: https://doi.org/15354/sief.21.re046 Rousseau, J.J. (2010). Émile ou de l'éducation. Flammarion.

Shi, Z. (2018). Back to the essence of education -Mr. Gu Mingyuan's discussion on the essence and value of education. Tsinghua Journal of Education, 39(5):4-11. [Chinese] DOI: https://doi.org/10.14138/j.1001-4519.2018.05.000408

Ushinsky, K. (2002). The human as a subject of education: Pedagogical anthropology. Moscow: URAO.

Wang, J. (2021). A Review of the development of the integration strategy of information technology and education in the four countries of the United States, Britain, China, and Singapore. Science Insights Education Frontiers, 9(2):1283-1303. DOI:

https://doi.org/10.15354/sief.21.re042

Yang, D. (2021). The essence of education is to educate people. Journal of the Chinese Society of Education, 42(8):3. [Chinese]

https://kns.cnki.net/KNS8/Detail?sfield=fn\&QueryID=0\&CurRec $=1 \&$ recid $=\&$ FileName $=$ ZJYX202108002 $\&$ DbName $=$ CJFDAUTO $\& D b C o$ $\mathrm{de}=\mathrm{CJFD} \& \mathrm{yx}=\& \mathrm{pr}=\mathrm{CFJD} 2021 ; \mathrm{CJFR} 2021 ; \& \mathrm{URLID}=$

Zhang, H. (2021). The construction of innovative education curriculum system for high school students: Based on the practice of "workshop + project" innovative education curriculum of Zhengzhou No. 12 Middle School, China. Science Insights Education Frontiers, 9(2):12651281. DOI: https://doi.org/10.15354/sief.21.or044

Correspondence to: Annalisa Morganti Associate professor in Special Education University of Perugia 06123 Perugia $(P G)$ Italy E-mail: annalisa.morganti@unipg.it $A N D$

Marta Pellegrini Fixed-Term Researcher Department of Education, Languages, Intercultures, Literatures and Psychology University of Florence 50121 Florence (FI) Italy

E-mail:marta.pellegrini@unifi.it

Conflict of Interests: None.

Doi: 10.15354/sief.21.ed022 